\title{
Clinical Presentation and Long-Term Outcomes of Systemic Sclerosis Portuguese Patients from a Single Centre Cohort: A EUSTAR Registration Initiative
}

\author{
Estudo Monocêntrico da Apresentação Clínica e \\ Prognóstico a Longo Prazo de Doentes Portugueses com \\ Esclerose Sistémica: Uma Iniciativa do Registo EUSTAR
}

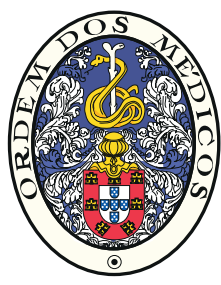

\author{
Carolina VIDAL ${ }^{1}$, Carina RUANO ${ }^{2}$, Vera BERNARDINO ${ }^{3}$, Pedro LAVADO CARREIRA ${ }^{3}$, Ana LLADÓ ${ }^{3}$, \\ Maria Céu SANTOS ${ }^{4}$, Heidi GRUNER ${ }^{3}$, António PANARRA ${ }^{3}$, Nuno RISO ${ }^{3}$, Maria Francisca MORAES-FONTES ${ }^{1}{ }^{1}$ \\ Acta Med Port 2018 Jun;31(6):312-320 • https://doi.org/10.20344/amp.10658
}

\section{ABSTRACT}

Introduction: Systemic sclerosis is a complex disorder that requires systematic screening. Our objective is to report the European Scleroderma Trials and Research group centre affiliation and its impact in our clinical practice.

Material and Methods: The European Scleroderma Trials and Research group affiliation process, database update and current patient evaluation, with respect to demographic and clinical features. Cumulative mortality was analysed.

Results: We identified 19 female patients (which met all the American College of Rheumatology/ European League Against Rheumatism 2013 criteria for systemic sclerosis) under current follow-up, divided according to the LeRoy classification into diffuse cutaneous (n $=5)$, limited cutaneous $(n=11)$ and limited $(n=3)$ types, followed for a median period of 5,12 and 6 years, respectively. Raynaud's phenomenon and abnormal nailfold capillaries were universally present. Interstitial lung disease was absent in the limited cutaneous form but present in $100 \%$ of the diffuse subtype. Pitting scars were more common in the diffuse form. Active disease was also more frequent in the diffuse form, and most patients with active disease were treated with anti-endothelin receptor antagonists. Over 21 years (from 1994 to 2015) the mortality rate was 55\% ( $n=23 / 42)$. Age at time of death was significantly lower in the diffuse subtype.

Discussion: Our single centre cohort shares many features with larger and international reports and more specifically is in accordance with patient characteristics described in the European Scleroderma Trials and Research group registries.

Conclusion: The European Scleroderma Trials and Research group registration motivated our systematic patient characterization and may be used as a tool for homogenous disease registries.

Keywords: Databases, Factual; Scleroderma, Systemic; Severity of Illness Index

\section{RESUMO}

Introdução: A esclerose sistémica é uma doença complexa que requer uma vigilância regular e sistemática. Este estudo teve como objetivo divulgar a afiliação da nossa Unidade no registo Europeu Scleroderma Trials and Research group e o seu impacto na prática clínica.

Material e Métodos: Processo de afiliação Scleroderma Trials and Research group, atualização da base de dados, avaliação sistemática das características demográficas e clínicas dos doentes em seguimento e análise da mortalidade cumulativa.

Resultados: Foram identificados 19 doentes do sexo feminino (com preenchimento completo dos critérios de classificação de esclerose sistémica do American College of Rheumatology/ European League Against Rheumatism 2013), seguidas no momento atual e divididas pela classificação de LeRoy em três formas: cutânea difusa $(n=5)$, cutânea limitada $(n=11)$ e limitada $(n=3)$, com um período de seguimento com uma duração mediana de 5, 12 e 6 anos, respetivamente. O fenómeno de Raynaud e as anomalias nos capilares peri-ungueais estavam presentes em todas as doentes. Todas as doentes com a forma difusa apresentavam doença intersticial pulmonar, ausente na forma cutânea limitada. As pitting scars foram mais frequentes na forma difusa. A doença ativa foi mais frequente na forma difusa, na sua maioria tratada com antagonistas dos recetores da endotelina. Num período de 21 anos (de 1994 a 2015), a mortalidade foi de $55 \%(n=23 / 42)$. A expectativa de vida nos doentes com a forma difusa estava significativamente reduzida quando comparada com a forma localizada.

Discussão: O nosso grupo de doentes é semelhante a outros de maiores dimensões e cariz internacional e, mais especificamente, enquadra-se nas características dos doentes registados nos registos Scleroderma Trials and Research group.

Conclusão: O registo Scleroderma Trials and Research group incentivou uma caracterização sistemática e pode revelar-se um veículo para a criação de registos mais homogéneos.

Palavras-chave: Bases de Dados Factuais; Esclerose Sistémica; Índice de Gravidade de Doença

\section{INTRODUCTION}

Systemic sclerosis (SSc) is a rare immune-mediated, multisystemic and heterogeneous disease of unknown aetiology, characterized by fibrosis and vasculopathy. ${ }^{1}$ While there is still significant SSc-related morbidity and mortality, earlier diagnosis and more effective treatment have significantly enhanced survival, in comparison to historical cohorts. ${ }^{2}$ An array of empirical therapies based on immunosuppressive therapy and vasodilators are

1. Serviço de Medicina Interna. Hospital do Divino Espírito Santo de Ponta Delgada. São Miguel. Portugal.

2. Serviço de Radiologia. Hospital de Santa Marta. Centro Hospitalar de Lisboa Central. Lisboa. Portugal.

3. Unidade de Doenças Auto-Imunes/Serviço Medicina 7.2. Hospital de Curry Cabral. Centro Hospitalar de Lisboa Central. Lisboa. Portugal.

4. Laboratório de Imunologia. Centro Hospitalar de Lisboa Central. Lisboa. Portugal.

$\triangle$ Autor correspondente: Maria Francisca Moraes-Fontes. mffontes@igc.gulbenkian.pt

Recebido: 13 de abril de 2018 - Aceite: 14 de maio de 2018 | Copyright @ Ordem dos Médicos 2018 
now recommended, based on large prospective cohort observations and expert opinions ${ }^{3-5}$ and some patients may benefit from autologous haematopoietic transplantation. ${ }^{6-8}$ Recognition of very early forms of SSc encompassed in the acronym VEDOSS (very early diagnosis of systemic sclerosis) hopes to identify patients in whom disease progression can be halted at an early stage. .-11 $^{\text {a }}$

Overall, regular screening is particularly important for the evaluation of patients with cardiopulmonary involvement, allowing for early diagnosis, determining disease progression and severity. Interstitial lung disease (ILD) has the greatest likelihood of responding to therapy when diagnosed early ${ }^{12}$ and accurately, as the extent of fibrosis is predictive of mortality. ${ }^{13-14}$ Of note, it has been recognized that there is great variability in the individual rate of lung function decline, ${ }^{15}$ contradicting historical studies that found the greatest loss occurred early in disease. ${ }^{16,17}$ Furthermore, the severity of pulmonary arterial hypertension (PAH) correlates inversely with survival. ${ }^{18,19}$

The European Scleroderma Trials and Research group (EUSTAR) was formed in 2004 and aims to foster the awareness, understanding and research of SSc and its management throughout Europe. In this study we characterize our patient cohort and demonstrate how EUSTAR database enrolment had a positive effect on our diagnostic, surveillance and therapeutic approach.

\section{MATERIAL AND METHODS EUSTAR registration}

The Unidade de Doenças Auto-imunes (Autoimmune Diseases Unit), Serviço Medicina 7.2, Hospital Curry Cabral, Centro Hospitalar de Lisboa Central, Lisbon, became affiliated with EUSTAR in 2015 (centre number 198). The affiliation process started with a request for authorization for patient registration to the Portuguese Data Protection Authority (Comissão Nacional de Protecção de Dados - CNPD) involving the submission of the original EUSTAR written information about its general organization and purpose, together with a Portuguese translation. Our Unit is affiliated with NEDAI/SPMI (Núcleo de Estudos de Doenças Autoimunes/Sociedade Portuguesa de Medicina Interna). Permission from the CNPD for EUSTAR patient registration was concomitantly sought and obtained for all Portuguese NEDAI centres. Once obtained, the CNPD permit was submitted to the Ethics Committee (EC) of our Hospital Centre, together with specifically written patient information and informed consent forms. EUSTAR online registration was completed after the Unit's database was updated and EC approval was obtained.

\section{Patient evaluation}

The Autoimmune Diseases Unit's SSc database was created in April 1994 and included 70 patients up to September 2015 . From these, nine were better classified by other disease entities, 13 had been lost to follow-up, 23 had died and VEDOSS was identified in six patients. SSc was confirmed in 19 patients under regular care (100\% fulfilment of current American College of Rheumatology/European League Against Rheumatism joint 2013 classification criteria). ${ }^{20}$ EUSTAR registration provided the backbone for database update and patient re-evaluation. SSc patients were prospectively recruited and further subdivided into the 2001 LeRoy clinical subtypes, ${ }^{21}$ namely: (i) a diffuse cutaneous form (dcSSc) which also affects the skin proximal to elbows and knees and is mostly associated to ILD, cardiac and gastrointestinal involvement; (ii) a limited cutaneous form (IcSSc) solely affecting distal extremities in association to Raynaud's phenomenon, digital ulcers and $\mathrm{PAH}$; and (iii) a limited form without cutaneous involvement (ISSc), also named sine scleroderma. Current demographic, ethnic and clinical features were noted including the modified Rodnan skin thickness score (mRSS), as well as past and present medications. Test results were retrieved and follow-up exams were requested if more than two years had elapsed since the last exam, namely nailfold videocapillaroscopy (NFC), thoracic high resolution computed tomography (HRCT) scan and respiratory function tests (RFT). Forced Vital Capacity [FVC], diffusing capacity of the lung for carbon monoxide [DLCO], DLCO Single Breath [DLCOSB], and DLCO corrected for alveolar volume [carbon monoxide transfer coefficient, or $\mathrm{KCO}$ ], \% of values predicted for age-, sex-, height-, and weight-matched healthy controls, were recorded as FVC, DLCOc and KCOc. ILD was staged based on HRCT disease extension and FVC, according to the system proposed by Wells and Colleagues ${ }^{22}$ and radiological features. ${ }^{23}$ None of the patients underwent lung biopsy. Oesophageal dilatation was determined by HRCT and diagnosed if the luminal coronal diameter of the oesophagus exceeded $10 \mathrm{~mm}$ - considering the internal limits of inner oesophageal mucosa. ${ }^{24}$ Upper gastrointestinal endoscopy and manometry (oesophageal/ anorectal) were performed in symptomatic patients. Resting transthoracic echocardiography was requested in all patients irrespective of symptoms, as a screening test for PAH. ${ }^{25}$ Mean Pulmonary Artery Pressure (mPAP) and peak Pulmonary Artery Systolic Pressure (pPASP) were derived from the regurgitant tricuspid flow by transthoracic echocardiography. The diagnosis of $\mathrm{PAH}$ was considered if pPASP was equal or superior to $37 \mathrm{~mm} \mathrm{Hg}^{26,27}$ or the DLCO was less than $60 \%$ of predicted. ${ }^{28}$ In such instances, patients were referred for cardiac catheterization to designated Pulmonary Hypertension Specialist Centres in the Lisbon region. Diagnosis of $\mathrm{PAH}$ using right heart catheterization (RHC) was defined as mean pulmonary arterial pressure $(\mathrm{mPAP}) \geq 25 \mathrm{mmHg}$ at rest with a mean pulmonary arterial wedge pressure (mPAWP) $\leq 15 \mathrm{mmHg}$. The validated European Scleroderma Study Group activity score for all SSc subtypes was applied (total maximum disease activity index of 10.0), with a cut-off point $>3$ for discriminating patients with active disease. The following activity scores were attributed as recommended: mRSS > $14-1.0$; Scleredema - 0.5; Delta-Skin - 2.0; Digital necrosis - 0.5; Delta-vascular - 0.5; Arthritis - 0.5; DLCO < 80\% - 0.5; Deltaheart, lung - 2.0; Erythrocyte sedimentation rate $>30 \mathrm{~mm} / 1^{\text {st }}$ 
h - 1.5; Hypocomplementaemia - 1.0. Delta change refers to deterioration of the relevant organ system as evaluated by the patient with respect to the previous month. ${ }^{29,30}$ Patients were treated according to the physician's judgement and expert recommendations. ${ }^{3}$ Mortality was considered for patients followed from $1994(n=23)$ but survival from initial visit was only available on 21 patients $(\mathrm{dcSSc}=4, \mathrm{lcSSc}=$ 10 , ISSc = 1, unknown = 6).

\section{Statistics}

Continuous variables were recorded as medians (interquartile ranges $[\mathrm{IQR}]$ ) and comparisons were made using Wilcoxon rank sum test. Dichotomous variables were examined by frequency distribution, recorded as proportions, and comparisons were made using Fisher's exact test. Nominal two-sided $p$-values of $<0.05$ were considered statistically significant. Analyses were performed using Statistical Package for the Social Sciences (SPSS version 23).

\section{RESULTS}

\section{Demographic and clinical characterization of current cohort}

Out of the 19 patients, five were classified as dcSSc, 11 as IcSSc, and three as ISSc (Table 1). All patients were female, 17 were White and two were African Black. The groups were homogenous for age and ethnicity. Not all patients were followed in our Unit from the time of diagnosis. Disease duration $(p=0.02)$ and follow-up $(p=0.04)$ were significantly longer in IcSSc when compared to dcSSc. There were no individual changes in disease subtype during the course of illness.

Regarding SSc diagnostic criteria, we followed the recommendation that finger skin thickening extending proximal to the metacarpophalangeal joints (MCP) was sufficient for the patient to be classified as having SSc. In its absence we applied the other additive items, each with varying weights. For each clinical subtype we show the presence of sclerodactily, telangiectasia, abnormal nail fold capillaries, ILD, PAH, Raynaud's phenomenon and SScrelated autoantibodies (Table 2). Raynaud's phenomenon and abnormal nailfold capillaries were universally present in all disease subtypes; only one patient was considered to have $\mathrm{PAH}$ because the echocardiographic estimated pPASP was $52 \mathrm{~mm} \mathrm{Hg}$, in the absence of severe ILD. There was, however, no opportunity to confirm the diagnosis through $\mathrm{RHC}$, due to severe co-morbidities. A single IcSSc patient failed to have a scleroderma pattern upon nail fold capillaroscopy. Digital ulcers were present in one dcSSC and three IcSSc at time of evaluation; two IcSSc patients had large ulcers in the lower limbs, one of whom had, consequently, undergone left leg below knee amputation. All patients with dcSSc had skin thickening proximal to the MCP joints, sclerodactily, pitting scars and telangiectasias. Diffuse and localized SSc patients were significantly differentiated by the presence of pitting scars $(p=0.03$ ) and ILD $(p<0.001)$, the latter particularly noticeable as it was absent in IcSSc, while present in every dcSSc patient. The small ISSc subgroup of patients was enriched for anti-centromere antibodies but otherwise there was no auto-antibody reactivity patterns with the other two patient subgroups. Of note, the only dcSSc patient who tested negative for the 2013 classification auto-antibody profile was anti-R052 positive and had been treated for breast cancer six years prior to the present report. No other cancer associated SSc patient was found. Only two dcSSc patients were ex-smokers, none being current smokers. Despite ongoing treatment, active disease was more frequent in dcSSc $(n=2 ; 40 \%)$ than in IcSSc, $(n=2 ; 29 \%$ - activity could not be calculated in four patients) but the difference between the two groups did not reach statistical significance $(p=1.000)$. Disease was active in one patient in the ISSc subtype.

\section{Extra-cutaneous organ manifestations}

Gastrointestinal disease in the form of oesophageal dysmotility was equally present in both groups. The frequency of oesophageal dilatation was higher in dcSSc $(100 \%)$ versus IcSSc (37\%) but not significantly different $(p=0.07)$ and present in one ISSc patient; another IcSSc patient complained of faecal incontinence in whom anal manometry revealed external sphincter dysfunction.

Two dcSSc patients had intermittent inflammatory arthritis of peripheral joints while it was not documented in any of the other patients. Two dcSSc patients suffered spontaneous rib fractures while on prednisolone $5 \mathrm{mg} /$ day. One patient with dcSSc (with a late presentation and eight year disease duration) with severe loco-regional acro-osteolysis and facial bone resorption suffered a spontaneous mandibular ramus and symphysis fractures (never subjected to steroid therapy). Mandibular resorption in SSc is relatively uncommon and is reported only in $10 \%$ of cases. ${ }^{31}$

Table 1 - Patient cohort: demographic characteristics according to the LeRoy clinical subtype

\begin{tabular}{lcccc}
\hline Characteristics & \multicolumn{3}{c}{ LeRoy subtype } & dcSSc vs IcSSc \\
& dcSSc & IcSSc & ISSc & - \\
$\mathrm{N}(\%)$ & $5(26)$ & $11(58)$ & $3(16)$ & $p=0.89$ \\
Current age (years) - median [IQR] & $54[54-60]$ & $58[49-75]$ & $72[46-75]$ & $p=1.00$ \\
Caucasian ethnicity - $\mathrm{n}(\%)$ & $4(80)$ & $10(91)$ & $3(100)$ & $p=0.02$ \\
Disease duration (years), median [IQR] & $8[5-9]$ & $14[9-21]$ & $6[3-17]$ & $p=0.04$ \\
Follow-up duration (years), median [IQR] & $5[3-9]$ & $12[6-15]$ & $6[3-17]$ & $p$ \\
\hline
\end{tabular}

dcSSc: diffuse cutaneous systemic sclerosis; IcSSc: limited cutaneous systemic sclerosis; ISSc: limited systemic sclerosis. Statistical tests: Wilcoxon rank sum test, Fisher's exact test 
Table 2 - Diagnostic criteria (EULAR/ACR 2013) according to the LeRoy clinical subtype

\begin{tabular}{|c|c|c|c|c|c|}
\hline Criteria & Sub-criteria & $\begin{array}{c}\text { dcSc } \\
(n=5)\end{array}$ & $\begin{array}{l}\text { IcSSc } \\
(n=11)\end{array}$ & $\begin{array}{l}\text { ISSc } \\
(n=3)\end{array}$ & dcSSc vs IcSSc \\
\hline \multirow[t]{3}{*}{ Cutaneous sclerosis; n (\%) } & $\begin{array}{l}\text { Skin thickening of fingers } \\
\text { proximal tothe MCP joints }\end{array}$ & $5(100)$ & $8(73)$ & 0 & $p=0.51$ \\
\hline & Puffy fingers & 0 & 0 & $2(67)$ & - \\
\hline & $\begin{array}{l}\text { Sclerodactily: whole finger } \\
\text { distal to MCP joint }\end{array}$ & $5(100)$ & $9(81)$ & 0 & $p=1.00$ \\
\hline \multirow[t]{2}{*}{ Fingertip lesions; n (\%) } & Digital tip ulcers & $1(20)$ & $3(27)$ & 0 & $p=1.00$ \\
\hline & Pitting scars & $5(100)$ & $3(27)$ & 0 & $p=0.03$ \\
\hline \multicolumn{2}{|l|}{ Telangiectasias; n (\%) } & $5(100)$ & $9(81)$ & $2(67)$ & $p=1.00$ \\
\hline \multicolumn{2}{|c|}{ Raynaud's phenomenon, n (\%) } & $5(100)$ & $11(100)$ & $3(100)$ & - \\
\hline \multicolumn{2}{|c|}{ Abnormal nailfold capillaries, n (\%) } & $5(100)$ & $11(100)$ & $3(100)$ & - \\
\hline \multirow[t]{2}{*}{ Lung; n (\%) } & $\mathrm{PAH}$ & $1(20)$ & 0 & 0 & $p=0.31$ \\
\hline & ILD & $5(100)$ & 0 & $1(33)$ & $p<0.0001$ \\
\hline \multirow[t]{4}{*}{ Auto-antibody; n (\%) } & Anti-centromere & $1(20)$ & $7(64)$ & $3(100)$ & $p=0.28$ \\
\hline & Anti-topoisomerase I & $3(60)$ & $2(18)$ & 0 & $p=0.24$ \\
\hline & Anti-RNA polymerase III & 0 & $2(18)$ & 0 & $p=1.00$ \\
\hline & Anti-Ro52 & $1(20)$ & 0 & 0 & $p=0.31$ \\
\hline
\end{tabular}

dcSSc: diffuse cutaneous systemic sclerosis; IcSSc: limited cutaneous systemic sclerosis; ISSc: limited systemic sclerosis. 2013 ACR/EULAR - American College of Rheumatology/ European League Against Rheumatism joint 2013 classification criteria. Statistical tests: Fisher's exact test.

Respiratory function tests, HRCT classification of ILD and Wells's staging system, pPASP, mPAP, presence of PAH and left ventricular shortening fraction (LVSF), according to LeRoy clinical subtype are shown in Table 3. Most patients with severe ILD according to the Wells' staging system, had nonspecific interstitial pneumonia (NSIP) and belonged to the dcSSc subgroup. One of the ISSc patients had a NSIP morphology with limited ILD. Using transthoracic echocardiography, PAH was suspected (pPASP $\geq 37 \mathrm{~mm} \mathrm{Hg}$ ) in four patients (two dcSSc and two IcSSc). Three of them performed RHC that revealed mPAP $\leq 25 \mathrm{~mm} \mathrm{Hg}$, thereby excluding the diagnosis of PAH. The fourth patient, with an estimated pPASP $=52 \mathrm{mmHg}$, in the absence of severe ILD, died during the study and RHC could not be performed. LVSF was similar in dcSSc and IcSSc and within normal values except for one patient with ISSc with LVSF $=35 \%$ (patient 18).

\section{Therapy}

Therapy reflected prior and current need for intensive immunosuppression in dcSSc patients (Table 4). In the latter, mycophenolate mofetil (MMF) was in each case preceded by cyclophosphamide regimens (varying from 0.75 to $1 \mathrm{~g} / \mathrm{m} 2$ administered monthly from 6 - 9 months) for the treatment of ILD. One dcSSc patient refused medication. Steroids (not higher than prednisolone $10 \mathrm{mg} /$ day) were previously used in six patients and progressively withdrawn. A single IcSSc patient is presently on prednisolone $(2.5 \mathrm{mg} /$ day). Methotrexate (MTX) was initially used in two IcSSc patients but stopped due to ineffectiveness in reducing skin sclerosis. Only two patients of the present cohort ever required iloprost infusions for severe vasospasm and digital ulceration. Overall, angiotensin-converting-enzyme (ACE) inhibitors or angiotensin II receptor blockers (ARB) were started prophylactically in all patients but progressively withdrawn except in those who were found to require anti-hypertensive medication. Calcium, vitamin D and proton pump inhibitors are prescribed for every patient. No scleroderma renal crisis (SRC) has been documented and none of our patients had an autologous stem cell or lung transplant. EUSTAR activity scores did not influence therapeutic choices. Except for one elderly patient with ISSc, all patients considered to have active disease (> 3.0) were treated with anti-endothelin receptor antagonists. In two patents there was a decline in FVC $>10 \%$ when compared to the previous year and they have been offered the possibility of emerging experimental therapies.

\section{Mortality}

The mortality rate was 55\% (23/42) over 21 years. We were unable to determine the LeRoy classification for six patients whose age at death and survival from initial visit were known. We classified four dcSSc, 10 IcSSc and one ISSc patients whose age at the time of death was known. There were two patients (one dcSSc and one from an unknown subtype) whose survival time was unavailable. The survival of the first two groups (dcSSc and IcSSc) is shown in Fig. 1. There was a higher survival in the IcSSc group but the difference was not statistically significant $(p=$ $0.67)$. Age at time of death was lower in the dcSSc patients compared to IcSSc patients $(p=0.03)$. ILD was a cause of death in one dcSSc patient. Cardiovascular complications (cardiac failure, fatal arrhythmia and peripheral ischemia) were the cause of six deaths (three dcSSc and three IcSSc). Infections were also reported as causes of three deaths in IcSSc subgroup and two of the unknown subtype group. Two patients died from malignancies (gastric carcinoma and metastasized squamous cell carcinoma from unknown 


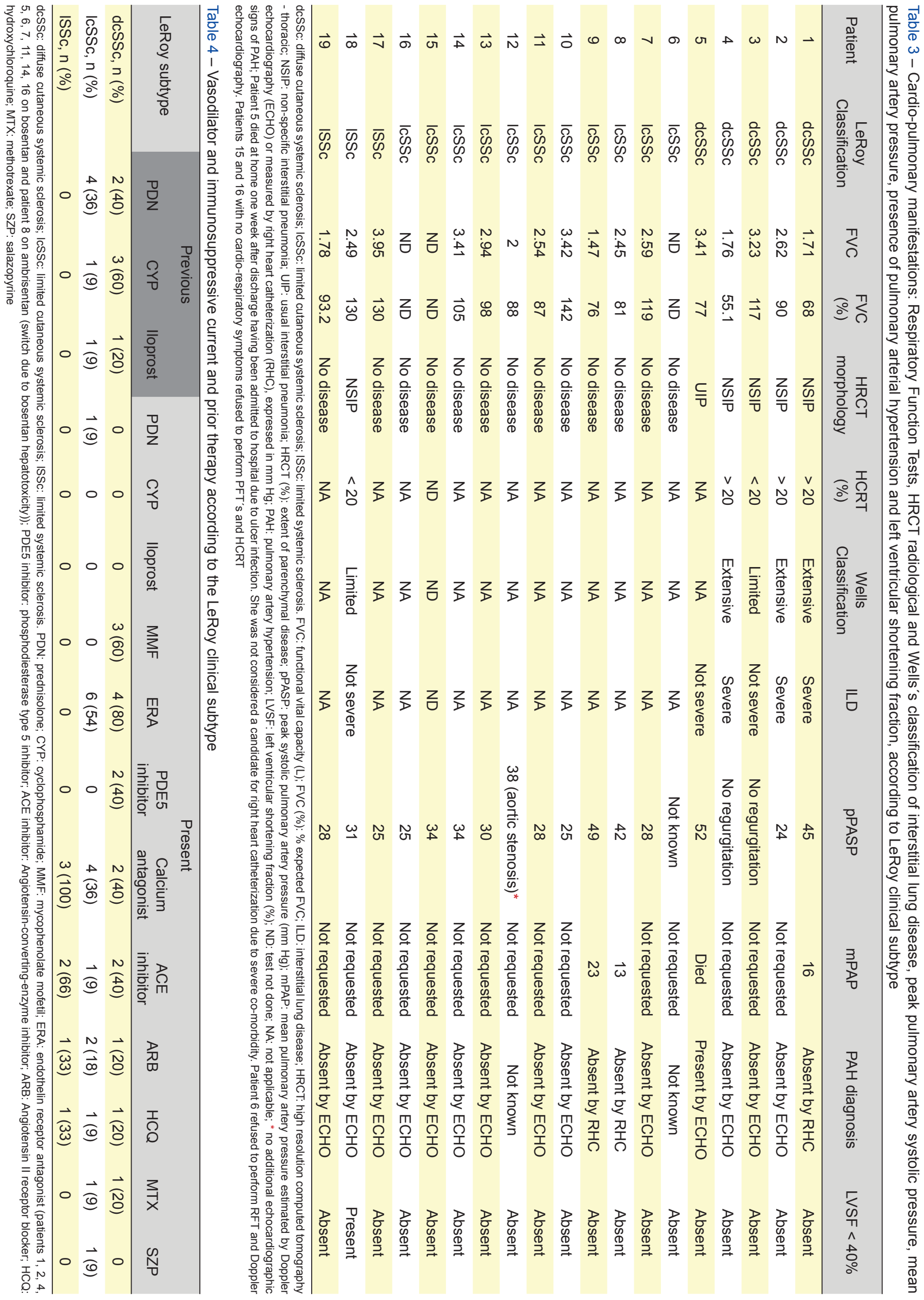




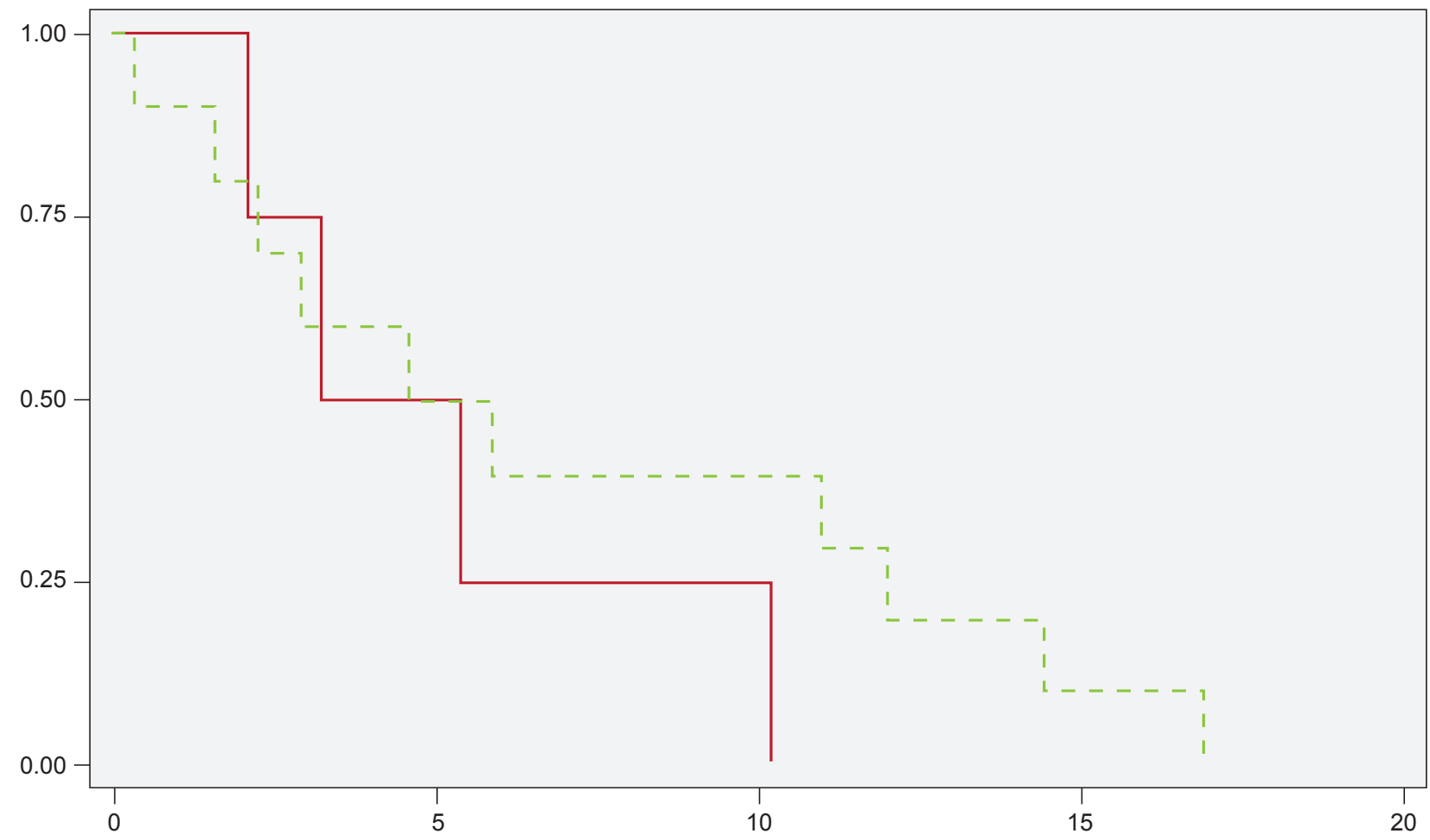

Years of survival after initial visit

$$
\operatorname{dcSSc}(n=4) \quad-\ldots, \operatorname{IcSSc}(n=10)
$$

Figure 1 - Survival of deceased patients grouped according to the LeRoy classification

origin), one with IcSSc and the other with an unknown subtype. We were unable to find the cause of death in the seven patients whose survival time was available (Table 5).

\section{DISCUSSION}

Systemic sclerosis is a rare disease with a reported prevalence in the general population ranging between 5.6 /100 000 in Taiwan ${ }^{32}$ to 24.2 /100 000 in the USA. ${ }^{33}$ Cohort descriptions of systemic sclerosis are recent and very scarce in Portugal, focusing on specific issues such as the clinical characteristics of hospitalized patients (retrospective review, $n=25$ ), ${ }^{34}$ basic research ${ }^{35}$ and biomarkers for digital ulceration, ${ }^{36}$ the latter two studies performed on a single centre cohort involving up to 77 patients.

We report a detailed description of 19 patients with SSc divided amongst each of the three LeRoy subgroups. All dcSSc patients had skin thickening, telangiectasias and Raynaud's phenomenon and presented with a higher frequency of pitting scars and ILD than those with IcSSc. These close associations have also been reported from a large centre cohort ${ }^{2}$ and from the first EUSTAR register report ${ }^{37}$. Raynaud's phenomenon, antinuclear antibodies and a typical capillaroscopic pattern were universally present, similarly to the following EUSTAR register report of over 7000 patients. ${ }^{38}$ Importantly, one ISSc patient had ILD, corroborating the possibility that ISSc patients may

Table 5 - Mortality according to LeRoy subtype and cause of death

\begin{tabular}{lcccc} 
& & \multicolumn{2}{c}{ LeRoy subtype } & Unknown* \\
\hline Number of patients & dcSSc & IcSSc & ISSc & 6 \\
Survival (years) from initial visit; median [IQR] & $4.3[2.71-7.83]$ & $5.25[2.25-12]$ & 5.5 & $7.3[4.75-10.08]$ \\
Age (years) at time of death; median [IQR] & $54[35-72]$ & $76.5[72-80]$ & 67 & $65.5[63-79]$ \\
Causes of death: & & & \\
Cardiovascular disease & 3 & 3 & 0 & 0 \\
ILD & 1 & 0 & 0 & 0 \\
Infection & 0 & 3 & 0 & 2 \\
Malignancy & 0 & 1 & 0 & 1 \\
Unknown & 0 & 3 & 1 & 3 \\
\hline
\end{tabular}

${ }^{*}$ survival unknown for one patient in each group. dcSSc: diffuse cutaneous systemic sclerosis; IcSSc: limited cutaneous systemic sclerosis; ISSc: limited systemic sclerosis. 
have internal organ damage, despite the absence of skin involvement. ${ }^{39}$ The small size of our patient cohort did not show statistically significant differences between the LeRoy subtypes in terms of auto-antibody reactivities even though, as predicted, ${ }^{2,35,40}$ we found that anti-topoisomerase I antibody positivity was more frequent in dcSSc while anti-centromere antibodies were more frequent in IcSSc. Significantly, the IcSSc subtype had a protective effect in relation to pulmonary fibrosis. Unlike the EUSTAR registry, we could not verify the finding that anti-centromere antibody positivity and $\mathrm{PAH}$ were more frequent in late onset disease. ${ }^{41}$ Despite the small size of the group, we found patients with features of each LeRoy subtype. However, within each group, heterogeneity of clinical phenotype and disease progression was significant. We therefore recognize that these patients might be better classified by molecular profiling as demonstrated by recent studies. ${ }^{42-44}$

Most of our patients had long standing disease without evidence of lung involvement on HCRT and adequate lung function indices, indicating a favourable prognosis. Changes in FVC and KCOc greater than $10 \%$ and $15 \%$, respectively, are associated with a poor outcome ${ }^{45,46}$ These findings had an individualized impact on the follow-up and therapeutic strategy. In addition, not unexpectedly, our patients with ILD had NSIP, the most typical pattern of lung involvement in SSc. ${ }^{47}$ Those patients with more severe NSIP were in the dcSSc subgroup. None of the patients that underwent $\mathrm{RHC}$ were found to have $\mathrm{PAH}$. Unlike previous descriptions of larger cohorts, ${ }^{2}$ measurements of pPASP obtained by echocardiography were similar in dcSSc and IcSSc groups. The low frequency of PAH in our patient group is in accordance with EUSTAR registry information in Western European countries. ${ }^{48}$

Concerning cumulative therapy, steroids, MMF, endothelin receptor antagonists, PDE5 inhibitors and prostanoids were more frequently prescribed in dcSSc. Cyclophosphamide was used more often in dcSSc than in IcSSc, as in the EUSTAR report. ${ }^{38}$ These results are expected as dcSSc patients had a higher percentage of active disease, ILD and digital vasculopathy, demanding a more aggressive therapeutic approach. ${ }^{3}$ Prophylactic ACE inhibitors and ARB were progressively withdrawn either due to intolerance or more recently based on the lack of evidence that these agents prevent SRC. ${ }^{49}$ Our patient cohort consisted of females predominantly affected by IcSSc. In accordance with previous characterizations, IcSSc patients had the highest survival and follow-up in the Unit. $2,33,37,50$

Regarding mortality, approximately half of fatalities were directly attributed to SSc, due to pulmonary fibrosis, pulmonary arterial hypertension, heart failure and arrhythmias. Non-SSc causes included infection, malignancies and cardiovascular disease, similar to data found in another studies. ${ }^{51}$ The retrospective nature and small sample size of our study does not allow for meaningful comparisons as regards mortality. Furthermore, some deceased patients may not have strictly fulfilled ACR/ EULAR 2013 criteria for SSc diagnosis.

\section{CONCLUSION}

Overall, the greatest limitation to our study is the small sample size. Nevertheless, our cohort fulfilled the characteristics previously described in large cohorts. Disease registries are traditionally regarded as beneficial because they provide information on real-life experience, resolve limitations posed by clinical trials, and overall contribute to scientific knowledge. They also improve disease management and patient empowerment. A potential added value to patient registries is the effect that it may have on clinical practice, an aspect that has remained largely unexplored. EUSTAR affiliation for patient registration had a positive impact in patient care in our centre. EUSTAR registration provided a practical framework for patient phenotyping, an update of screening procedures and an internal review of patient's therapy suitability on an individual basis, according to current recommendations for disease management. It therefore allowed us to characterize a small patient cohort, which was representative of the main disease subtypes. Beyond the obvious advantages of using clinical data to contribute to medical knowledge at a national and European level, we encourage EUSTAR registration as we demonstrate its favourable impact on clinical care.

\section{ACKNOWLEDGEMENTS}

A brief summary of this work was published in 2017 as a Letter to the Editor in the Journal of Scleroderma and Related Disorders, a non-PUBMED indexed publication.

\section{PROTECTION OF HUMANS AND ANIMALS}

All procedures performed were in accordance with the ethical standards of the Institutional Ethics Committee [(Comissão de Ética do Centro Hospitalar de Lisboa Central; approval number 160 (2014)] and the National Protection Data Comission [(Comissão Nacional de Protecção de Dados; approval number 0342 (2014)].

\section{DATA CONFIDENTIALITY}

The authors declare having followed the protocols in use at their working center regarding patients' data publication. Patient consent obtained.

\section{CONFLICTS OF INTEREST}

The authors declare that they have no conflict of interest.

\section{FUNDING SOURCES}

This research received no specific grant from any funding agency in the public, commercial, or not-for-profit sectors.

\section{INFORMED CONSENT}

Informed consent was obtained from all individual participants included in the study. 


\section{REFERENCES}

1. Gabrielli A, Avvedimento EV, Krieg T. Scleroderma. N Engl J Med. 2009;360:1989-2003.

2. Nihtyanova SI, Schreiber BE, Ong VH, Rosenberg D, Moinzadeh P, Coghlan JG, et al. Prediction of pulmonary complications and long-term survival in systemic sclerosis. Arthritis Rheum. 2014;66:1625-35.

3. Kowal-Bielecka O, Landewe R, Avouac J, Chwiesko S, Miniati I, Czirjak $\mathrm{L}$, et al. EULAR recommendations for the treatment of systemic sclerosis: a report from the EULAR Scleroderma Trials and Research group (EUSTAR). Ann Rheum Dis. 2009;68:620-8.

4. Nihtyanova SI, Ong VH, Denton CP. Current management strategies for systemic sclerosis. Clin Exp Rheumatol. 2014;32:S156-64.

5. Denton CP, Hughes M, Gak N, Vila J, Buch MH, Chakravarty K, et al. BSR and BHPR guideline for the treatment of systemic sclerosis. Rheumatology. 2016;55:1906-10.

6. Burt RK, Shah SJ, Dill K, Grant T, Gheorghiade M, Schroeder J, et al. Autologous non-myeloablative haemopoietic stem-cell transplantation compared with pulse cyclophosphamide once per month for systemic sclerosis (ASSIST): an open-label, randomised phase 2 trial. Lancet. 2011;378:498-506.

7. van Laar JM, Farge D, Sont JK, Naraghi K, Marjanovic Z, Larghero J, et al. Autologous hematopoietic stem cell transplantation vs intravenous pulse cyclophosphamide in diffuse cutaneous systemic sclerosis: a randomized clinical trial. JAMA. 2014;311:2490-8.

8. Burt RK, Oliveira MC, Shah SJ, Moraes DA, Simoes B, Gheorghiade $M$, et al. Cardiac involvement and treatment-related mortality after nonmyeloablative haemopoietic stem-cell transplantation with unselected autologous peripheral blood for patients with systemic sclerosis: a retrospective analysis. Lancet. 2013;381:1116-24.

9. Minier T, Guiducci S, Bellando-Randone S, Bruni C, Lepri G, Czirjak $\mathrm{L}$, et al. Preliminary analysis of the very early diagnosis of systemic sclerosis (VEDOSS) EUSTAR multicentre study: evidence for puffy fingers as a pivotal sign for suspicion of systemic sclerosis. Ann Rheum Dis. 2014;73:2087-93.

10. Lepri G, Guiducci S, Bellando-Randone S, Giani I, Bruni C, Blagojevic J, et al. Evidence for oesophageal and anorectal involvement in very early systemic sclerosis (VEDOSS): report from a single VEDOSS/EUSTAR centre. Ann Rheum Dis. 2015;74:124-8.

11. Bruni C, Guiducci S, Bellando-Randone S, Lepri G, Braschi F, Fiori G, et al. Digital ulcers as a sentinel sign for early internal organ involvement in very early systemic sclerosis. Rheumatology. 2015;54:72-6.

12. Steen VD, Lanz JK, Jr., Conte C, Owens GR, Medsger TA, Jr. Therapy for severe interstitial lung disease in systemic sclerosis. A retrospective study. Arthritis Rheum. 1994;37:1290-6.

13. Komocsi A, Vorobcsuk A, Faludi R, Pinter T, Lenkey Z, Kolto G, et al. The impact of cardiopulmonary manifestations on the mortality of SSc: a systematic review and meta-analysis of observational studies. Rheumatology. 2012;51:1027-36.

14. Moore OA, Goh N, Corte T, Rouse H, Hennessy O, Thakkar V, et al. Extent of disease on high-resolution computed tomography lung is a predictor of decline and mortality in systemic sclerosis-related interstitial lung disease. Rheumatology. 2013;52:155-60.

15. Man A, Davidyock T, Ferguson LT, Leong M, Zhang Y, Simms RW. Changes in forced vital capacity over time in systemic sclerosis: application of group-based trajectory modelling. Rheumatology. 2015;54:1464-71.

16. Steen VD, Conte C, Owens GR, Medsger TA, Jr. Severe restrictive lung disease in systemic sclerosis. Arthritis Rheum. 1994;37:1283-9.

17. Plastiras SC, Karadimitrakis SP, Ziakas PD, Vlachoyiannopoulos PG, Moutsopoulos HM, Tzelepis GE. Scleroderma lung: initial forced vital capacity as predictor of pulmonary function decline. Arthritis Rheum. 2006;55:598-602.

18. Lefevre G, Dauchet L, Hachulla E, Montani D, Sobanski V, Lambert M, et al. Survival and prognostic factors in systemic sclerosis-associated pulmonary hypertension: a systematic review and meta-analysis. Arthritis Rheum. 2013;65:2412-23.

19. Williams MH, Das C, Handler CE, Akram MR, Davar J, Denton CP, et al. Systemic sclerosis associated pulmonary hypertension: improved survival in the current era. Heart. 2006;92:926-32.

20. van den Hoogen F, Khanna D, Fransen J, Johnson SR, Baron M, Tyndall A, et al. 2013 classification criteria for systemic sclerosis: an American College of Rheumatology/European League against Rheumatism collaborative initiative. Arthritis Rheum. 2013;65:2737-47.

21. LeRoy EC, Medsger TA, Jr. Criteria for the classification of early systemic sclerosis. J Rheumatol. 2001;28:1573-6.
22. Goh NS, Desai SR, Veeraraghavan S, Hansell DM, Copley SJ, Maher TM, et al. Interstitial lung disease in systemic sclerosis: a simple staging system. Am J Respir Crit Care Med. 2008;177:1248-54.

23. Ruano CA, Lucas RN, Leal Cl, Lourenco J, Pinheiro S, Fernandes O, et al. Thoracic manifestations of connective tissue diseases. Curr Probl Diagn Radiol. 2015;44:47-59.

24. Bhalla M, Silver RM, Shepard JA, McLoud TC. Chest CT in patients with scleroderma: prevalence of asymptomatic esophageal dilatation and mediastinal lymphadenopathy. AJR Am J Roentgenol. 1993;161:269-72.

25. Humbert M, Yaici A, de Groote P, Montani D, Sitbon O, Launay D, et al. Screening for pulmonary arterial hypertension in patients with systemic sclerosis: clinical characteristics at diagnosis and long-term survival. Arthritis Rheum. 2011;63:3522-30

26. Galie N, Hoeper MM, Humbert M, Torbicki A, Vachiery JL, Barbera $\mathrm{JA}$, et al. Guidelines for the diagnosis and treatment of pulmonary hypertension: the Task Force for the Diagnosis and Treatment of Pulmonary Hypertension of the European Society of Cardiology (ESC) and the European Respiratory Society (ERS), endorsed by the International Society of Heart and Lung Transplantation (ISHLT). Eur Heart J. 2009;30:2493-537.

27. Chaisson NF, Hassoun PM. Systemic sclerosis-associated pulmonary arterial hypertension. Chest. 2013;144:1346-56.

28. Coghlan JG, Denton CP, Grunig E, Bonderman D, Distler O, Khanna D, et al. Evidence-based detection of pulmonary arterial hypertension in systemic sclerosis: the DETECT study. Ann Rheum Dis. 2014;73:13409.

29. Valentini G, Bencivelli W, Bombardieri S, D'Angelo S, Della Rossa A, Silman AJ, et al. European Scleroderma Study Group to define disease activity criteria for systemic sclerosis. III. Assessment of the construct validity of the preliminary activity criteria. Ann Rheum Dis. 2003;62:9013.

30. Valentini G, Silman AJ, Veale D. Assessment of disease activity. Clin Exp Rheumatol. 2003;21:S39-41.

31. Auluck A, Pai K, Shetty C, Shenoi S. Mandibular resorption in progressive systemic sclerosis: a report of three cases. Dentomaxillofac Radiol. 2005;34:384-6.

32. Kuo CF, See LC, Yu KH, Chou IJ, Tseng WY, Chang HC, et al. Epidemiology and mortality of systemic sclerosis: a nationwide population study in Taiwan. Scand J Rheumatol. 2011;40:373-8.

33. Mayes MD, Lacey JV, Jr., Beebe-Dimmer J, Gillespie BW, Cooper B, Laing TJ, et al. Prevalence, incidence, survival, and disease characteristics of systemic sclerosis in a large US population. Arthritis Rheum. 2003;48:2246-55.

34. Silva L, Videira T, Brandao F, Pinto J, Brito JS, Ventura FS. Hospitalização de doentes com esclerose sistémica: caracterização de uma população. Acta Reumatol Port. 2010;35:42-9.

35. Almeida I, Silva SV, Fonseca AR, Silva I, Vasconcelos C, Lima M. T and NK Cell Phenotypic Abnormalities in Systemic Sclerosis: a Cohort Study and a Comprehensive Literature Review. Clin Rev Allergy Immunol. 2015;49:347-69

36. Silva I, Almeida C, Teixeira A, Oliveira J, Vasconcelos C. Impaired angiogenesis as a feature of digital ulcers in systemic sclerosis. Clin Rheumatol. 2016;35:1743-51.

37. Walker UA, Tyndall A, Czirjak L, Denton C, Farge-Bancel D, KowalBielecka $O$, et al. Clinical risk assessment of organ manifestations in systemic sclerosis: a report from the EULAR Scleroderma Trials And Research group database. Ann Rheum Dis. 2007;66:754-63.

38. Meier FM, Frommer KW, Dinser R, Walker UA, Czirjak L, Denton CP, et al. Update on the profile of the EUSTAR cohort: an analysis of the EULAR Scleroderma Trials and Research group database. Ann Rheum Dis. 2012;71:1355-60.

39. Poormoghim H, Lucas M, Fertig N, Medsger TA, Jr. Systemic sclerosis sine scleroderma: demographic, clinical, and serologic features and survival in forty-eight patients. Arthritis Rheum. 2000;43:444-51.

40. Steen VD, Powell DL, Medsger TA, Jr. Clinical correlations and prognosis based on serum autoantibodies in patients with systemic sclerosis. Arthritis Rheum. 1988;31:196-203.

41. Hugle T, Schuetz P, Daikeler T, Tyndall A, Matucci-Cerinic M, Walker UA, et al. Late-onset systemic sclerosis--a systematic survey of the EULAR scleroderma trials and research group database. Rheumatology. 2011;50:161-5

42. Milano A, Pendergrass SA, Sargent JL, George LK, McCalmont TH, Connolly MK, et al. Molecular subsets in the gene expression signatures of scleroderma skin. PLoS One. 2008;3:e2696 
43. Hinchcliff M, Huang CC, Wood TA, Matthew Mahoney J, Martyanov V, Bhattacharyya $\mathrm{S}$, et al. Molecular signatures in skin associated with clinical improvement during mycophenolate treatment in systemic sclerosis. J Invest Dermatol. 2013;133:1979-89.

44. Johnson ME, Mahoney JM, Taroni J, Sargent JL, Marmarelis E, Wu MR, et al. Experimentally-derived fibroblast gene signatures identify molecular pathways associated with distinct subsets of systemic sclerosis patients in three independent cohorts. PLoS One. 2015;10:e0114017.

45. Zappala CJ, Latsi PI, Nicholson AG, Colby TV, Cramer D, Renzoni EA, et al. Marginal decline in forced vital capacity is associated with a poor outcome in idiopathic pulmonary fibrosis. Eur Respir J. 2010;35:830-6.

46. du Bois RM, Weycker D, Albera C, Bradford WZ, Costabel U, Kartashov A, et al. Ascertainment of individual risk of mortality for patients with idiopathic pulmonary fibrosis. Am J Respir Crit Care Med. 2011;184:45966.

47. Fujita J, Yoshinouchi T, Ohtsuki Y, Tokuda M, Yang Y, Yamadori I, et al. Non-specific interstitial pneumonia as pulmonary involvement of systemic sclerosis. Ann Rheum Dis. 2001;60:281-3.

48. Walker UA, Tyndall A, Czirjak L, Denton CP, Farge-Bancel D, KowalBielecka O, et al. Geographical variation of disease manifestations in systemic sclerosis: a report from the EULAR Scleroderma Trials and Research (EUSTAR) group database. Ann Rheum Dis. 2009;68:856-62.

49. Penn $\mathrm{H}$, Denton CP. Diagnosis, management and prevention of scleroderma renal disease. Curr Opin Rheumatol. 2008;20:692-6.

50. Ioannidis JP, Vlachoyiannopoulos PG, Haidich AB, Medsger TA, Jr., Lucas M, Michet CJ, et al. Mortality in systemic sclerosis: an international meta-analysis of individual patient data. Am J Med. 2005;118:2-10.

51. Tyndall AJ, Bannert B, Vonk M, Airo P, Cozzi F, Carreira PE, et al. Causes and risk factors for death in systemic sclerosis: a study from the EULAR Scleroderma Trials and Research (EUSTAR) database. Ann Rheum Dis. 2010;69:1809-15. 